\title{
ОРГАНІЗАЦЙНО-МЕТОДИЧНІ АСПЕКТИ ПРАКТИЧНОЇ ПІДГОТОВКИ СТУДЕНТІВ У ДОНЕЦЬКОМУ НАЦІОНАЛЬНОМУ МЕДИЧНОМУ УНІВЕРСИТЕТІ ПРИ КРЕДИТНО-МОДУЛЬНІЙ СИСТЕМІ НАВЧАННЯ: ПРОБЛЕМИ ТА ПЕРСПЕКТИВИ
}

\author{
Ю. В. Думанський, О. М. Талалаєнко, В. І. Черній, М. Б. Первак, Н. Ю. Костюкова \\ Донецький національний медичний університет імені М. Горького

\section{ORGANIZING AND METHODICAL ASPECTS OF STUDENTS' PRACTICAL TRAINING AT DONETSK NATIONAL MEDICAL UNIVERSITY AT CREDIT-MODULAR SYSTEM: PROBLEMS AND PROSPECTS}

\author{
Yu.V. Dumanskyi, O. M. Talalayenko, V. I. Cherniy, M. B. Pervak, N. Yu. Kostyukova \\ Donetsk National Medical University by M. Hovkyi
}

\begin{abstract}
У статті проаналізовано стан практичної підготовки студентів у Донецькому національному медичному університеті при кредитно-модульній системі навчання. Визначено організаційно-методичні аспекти цього виду навчання та наведено комплекс реалізованих та запланованих заходів, спрямованих на підвищення його ефективності.
\end{abstract}

In the article the analysis of the state of students' practical training at credit-modular system at Donetsk National Medical University was given. Organizing and methodical aspects of this kind of training were determined. The complex of realized and planned measures for its improving was described.

Вступ. Останнім часом як в Україні, так і в інших країнах Європи в академічному середовищі і в суспільстві багато уваги приділяють реалізації так званого компетентністного підходу до навчання, який вимагає орієнтування всього процесу підготовки фахівця на кінцеві результати - оволодіння ним компетенціями, необхідними для майбутньої професійної діяльності. Особливого значення реалізація такого підходу має у медичній освіті $[2,5,6]$. У зв'язку з цим ще у 2005 р. у країнах Євросоюзу у межах проекту “TUNING” було розпочато дослідження з визначення всіх універсальних та суто професійних компетенцій, обов' язкових для випускників вищих медичних шкіл. В Україні аналогічна робота була проведена раніше і результати ії були реалізовані у чинних державних стандартах медичної освіти на рівні “спеціаліст" [3]. Відповідно до сформульованих у цих документах вимог майбутній лікар під час навчання у вищому медичному навчальному закладі (BН3) має не лише оволодіти значним обсягом знань, але й отримати якісну практичну підготовку. За умов розпочатого в країні реформування вітчизняної системи охорони здоров'я роль цього компонента у формуванні лікаря на додипломному етапі суттєво зростає, проте організаційні та методичні засади практичної підготовки студентів при кредитно-модульній системі навчання досі не визначені.

Основна частина. На початку минулого навчального року, коли на випускаючі кафедри вперше прийшли “вихованці” кредитно-модульної системи, у Донецькому національному медичному університеті ім. М. Горького (ДонНМУ) було відзначено зниження рівня практичної підготовки студентів. Аналогічна ситуація відмічена нашими колегами і в інших медичних ВН3 країни. Причини їі неодноразово обговорювалися і $€$ добре відомими. Серед них як гонитва за кращими результатами ліщензійних тестових іспитів, так і низка об'єктивних обставин: недостатнє фінансування для навчання малими групами, проблеми з виробничою практикою, що виникли останніми роками, неврегульованість правових аспектів залучення пацієнтів до навчального процесу, інколи відсутність тематичних хворих тощо.

Для зміни ситуації на краще керівництвом нашого університету було створено робочу групу, яку очолив перший проректор і до якої увійшли керівник галузевої науково-методичної лабораторії з питань додипломної підготовки лікарів, голови методичних профільних комісій та завідувачі випускаючих кафедр.

\footnotetext{
( Ю. В. Думанський, О. М. Талалаєнко, В. І. Черній та ін.
} 
Перш за все, членами групи на базі вимог чинних державних стандартів медичної освіти [3] та відповідно до реалізованої у ДонНМУ системи управління якістю підготовки фахівців $[1,2,4]$ було підготовлено 4 окремі книжки практичних навичок (індивідуальні плани практичної підготовки) - для всіх медичних спеціальностей, за якими у нашому ВНЗ проходить навчання на додипломному рівні: “Лікувальна справа”, “Педіатрія”, “Медико-профілактична справа”, “Стоматологія".

3 вересня 2011 р. у ДонНМУ було відновлено забуту при впровадженні кредитно-модульної системи практику атестації практичної підготовки майбутніх лікарів. Індивідуальні плани з цього виду навчання стали обов'язковим документом для всіх студентів 2 курсу стоматологічного та всіх студентів 3 курсу медичних факультетів.

Кожна 3 цих книжок складається 33 розділів - таких, як: 1) наскрізна програма практичних навичок 3 певної спеціальності; 2) облік освоєння практичних навичок на конкретних кафедрах; 3) облік освоєння практичних навичок під час виробничої практики (по курсах і профілях). Важливим, на нашу думку, є те, що на кожному етапі проти кожної навички зазначено так звану мінімальну кількість разів правильного виконання. Лише за умови, що за період навчання з цієї дисципліни (або під час практики) студент продемонстрував викладачу володіння цієї навичкою у кількості разів, не менш за мінімальну, викладач напроти неї зазначає своє прізвище та ставить підпис. Сподіваємось, це сприятиме підвищенню відповідальності кафедр і окремих викладачів за цей розділ роботи.

В розділі “навчання на кафедрах” всі практичні навички розподілені на дві групи: такі, що можуть бути освоєні лише при роботі з пацієнтом, і такі, які на першому етапі можуть бути освоєні при роботі з тренажерами, фантомами, муляжами тощо.

Для підвищення рівня освоєння студентами другої групи практичних навичок керівництвом нашого університету було організовано окремий Центр практичної підготовки загальною площею близько 150 кв. м.

Базуючись на одному з основних положень педагогіки, що для якісного освоєння будь-якого вміння необхідне неодноразове його повторення, ми плануємо, що у створеному Центрі будуть проходити навчання навичкам акушерсько-гінекологічного профілю студенти 4-6 курсів медичних факультетів, а навичкам терапевтичного, хірургічного та педіатричного профілів - студенти 3-6 курсів. У поточному році означений вище Центр вже став базою навчання для студентів 3 курсу всіх медичних факультетів.
Студенти стоматологічного факультету, як і раніше, опановують необхідні їм навички у так званому фантомному залі на кафедрі пропедевтичної стоматології протягом 2 курсу.

Зрозуміло, що ефективність цих заходів можна буде оцінити лише через декілька років. Але для визначення, умовно кажучи, “точки відліку” нами заплановано дослідження з визначення рівня практичної підготовки випускників цього року як за матеріалами державних практично-орієнтованих іспитів, так i за результатами соціологічного опитування наприкінці ї навчання у ДонНМУ.

Для останнього було розроблено спеціальні анкети, які для випускників медичних факультетів містять 55 практичних навичок, для випускників стоматологічного факультету - 82 (суто стоматологічні та загальнолікарські).

Проти кожної з навичок респондент мав зазначити “рівень знайомства” з нею: бачив, як виконує викладач; виконував самостійно на клінічних кафедрах при роботі з муляжами, фантомами (кількість разів), при обстеженні пацієнтів (кількість разів); під час виробничої практики (кількість разів).

У зв'язку із скороченням поточного навчального року і наближенням ліщензійних іспитів ми вже в квітні за допомогою цих анкет провели анкетування 220 студентів 6 курсу медичних факультетів та 130 студентів стоматологічного. Через зрозумілий брак часу поки що здійснена лише первинна обробка отриманих даних.

Результати опитування окремого респондента були порівняні з вимогами, означеними у запроваджених поточного року індивідуальних планах практичної підготовки студентів.

Зокрема, зіставляли зазначену опитуваними кількість разів виконання певної навички під час навчання на різних клінічних кафедрах (при роботі 3 муляжами, фантомами та при дослідженні пацієнтів) та під час виробничої практики із кількістю, що встановлена як мінімальна.

Рівень оволодіння навичкою вважали високим, якщо від 75 до $100 \%$ респондентів зазначили кількість разів виконання не менш за мінімальну, середнім - якщо зазначена кількість була достатньою у 50-74 \% опитаних і низьким - якщо частота позначення достатньої кількості була меншою за 50 \%.

Попередній аналіз результатів показав високий рівень оволодіння більшістю практичних навичок, які реалізуються при фізикальному обстеженні пацієнтів: перкусія та аускультація легень, серця, пальпація судин, живота, молочних залоз, визначення частоти 
пульсу тощо (від 75 до 100 \% респондентів зазначили кількість разів виконання не менш мінімальної). Втішною виявилася і ситуація з більшістю акушерських навичок: для вимірювання розмірів таза, зовнішнього акушерського обстеження вагітних за Леопольдом, визначення маси плода зазначена кількість разів лише у 25 \% опитуваних була меншою, ніж мінімальна. Багаторічне використання на кафедрах акушерства і гінекології якісних фантомів та муляжів забезпечило високий рівень оволодіння такими навичками, як огляд шийки матки у дзеркалах, бімануальне дослідження жінки, взяття матеріалу з піхви, уретри, цервікального каналу, надання акушерської допомоги щодо захисту промежини при фізіологічних пологах, штучна вентиляція легень та непрямий масаж серця при асфіксії новонародженого.

Низьким рівень засвоєння, за даними соціологічного дослідження, виявився для таких практичних навичок, як ін'єкції лікарських речовин, особливо внутрішньовенних, промивання шлунка, кишечника, визначення групи крові стандартними сироватками та визначення резус-приналежності, пальцеве дослідження прямої кишки, катетеризація сечового міхура м'яким зондом. Можливо, це значною мірою зумовлене наявністю останнім часом проблем з повноцінним проведенням виробничої практики. Маємо надію,

\section{Література}

1. Методологія і реалізація системи управління якістю медичної освіти [В. М. Казаков, О. М. Талалаєнко, М. Г. Гаріна та ін.]. - Донецьк, 2001.-213 с.

2. Опыт управления учебной деятельностью студентов при реализации компетентностного подхода / [Ю. В. Думанский, В. Н. Казаков, А. Н. Талалаенко и др.]. - Москва, 2010. -64 с.

3. Складові галузевих стандартів вищої освіти напряму підготовки 1101 “Медицина” освітньо-кваліфікаційного рівня “спеціаліст” за спеціальностями “Лікувальна справа”, "Педіатрія", "Медико-профілактична справа”. - Київ : Міністерство освіти і науки України, 2003. - 369 с. що функціонування Центру практичної підготовки студентів, оснащеного тренажерами, фантомами та муляжами, необхідними для відпрацювання всіх означених вище навичок, дозволить нам змінити ситуацію на краще.

По завершенні ретельної обробки всіх анкет отримані дані будуть порівняні з матеріалами практичноорієнтованих іспитів поточного року. Після цього буде проведено аналіз причин недостатнього забезпечення кожної з практичних навичок, для якої рівень освоєння виявився низьким або середнім.

У зв'язку з реформуванням вітчизняної системи охорони здоров' я та підвищенням ролі первинної ланки надання медичної допомоги розроблену для додипломного рівня навчання наскрізну програму освоєння практичних навичок було зіставлено з програмою навчання і кваліфікаційними вимогами лікарів-інтернів за спеціальністю “Загальна практика, сімейна медицина" і на основі цих документів розроблено індивідуальні плани практичної підготовки в інтернатурі з вищеозначеної спеціальності.

Висновок. Вважаємо, що всі реалізовані та заплановані нами заходи дозволять розробити єдину систему практичної підготовки студентів у медичному ВНЗ і суттєво підвищити ефективність навчання студентів практичних навичок.

4. Управление качеством подготовки специалистов : программно-целевой подход (на примере высшего и послевузовского медицинского образования) / [В. Н. Казаков, Н. А. Селезнева, А. Н. Талалаенко и др.]. - [2-е изд.]. - Москва, 2007. -215 c.

5. Abstracts of Conference of Association for Medical Education in Europe. - Vienna, 2008. - 479 p.

6. Dent J. A., Harden R.M. A practical guide for medical teachers. - Churchill Livingstone Elsevier: Edinburgh, London, New York, Oxgord, Philadelphia, St.Louis, Sydney, Toronto, 2009. $-435 \mathrm{p}$. 